\title{
Cocoa Agro-Industrial Residue (Theobroma cacao) as Inducer of the Production of Fungal Laccase and Kojic Acid for Application in the Biodegradation of 17- $\alpha$-Ethinylestradiol
}

\author{
Jhéssica C. S. Golveia, ${ }^{\circledR a}$ Maria Teresa F. Bara, ${ }^{\circledR a}$ Mariângela F. Santiago, ${ }^{\circledR a}$ \\ Luiza C. Campos ${ }^{\circledR b}$ and Fernando Schimidt ${ }^{\circledR} * c$ \\ ${ }^{a}$ Faculdade de Farmácia, Universidade Federal de Goiás, 74605-170 Goiânia-GO, Brazil \\ ${ }^{b}$ Department of Civil, Environmental and Geomatic Engineering, University College London, \\ WC1E 6BT London, United Kingdom \\ 'Instituto Federal de Educação, Ciência e Tecnologia de Goiás (IFG), 74055-110 Goiânia-GO, Brazil
}

\begin{abstract}
Due to the ability to catalyze the oxidation of several substrates, the enzyme laccase has been used in several applications, among them the bioremediation of emerging pollutants. This work evaluate the capacity of the cocoa agro-industrial residue to induce the production of Pycnoporus sanguineus laccase and to apply the enzymatic extract in the biodegradation of 17- $\alpha$-ethinylestradiol (EE2). The macro and micronutrient levels of the cocoa residue were previously evaluated to establish correlations with induction of enzymatic production. The fungus was cultured for 7 days at $28{ }^{\circ} \mathrm{C}$ and shaking at $150 \mathrm{rpm}$. For the biodegradation, the enzymatic extract of laccase was added to the solution of EE2 and the percentage of removal was evaluated. The production of enzyme extract was notably increased by the addition of only $1 \%\left(\mathrm{~m} \mathrm{v}^{-1}\right)$ of agro-industrial cocoa residue. Laccase activity reached $3920 \mathrm{U} \mathrm{mL}^{-1}$ on the $7^{\text {th }}$ day of cultivation, being superior to the positive control $\left(511 \mathrm{U} \mathrm{mL}^{-1}\right)$. The percentage of EE2 removal was $63 \%$ after $4 \mathrm{~h}$, and after $8 \mathrm{~h}$ of reaction the EE2 concentration was below the limit of detection (LOD, $0.35 \mu \mathrm{g} \mathrm{mL} \mathrm{m}^{-1}$ ). Analysis showed the presence of kojic acid in the enzyme extract, constituting a powerful redox mediator, capable of enhancing the action of laccase.
\end{abstract}

Keywords: agro-waste, polyphenoloxidase, redox mediator, sustainability, laccase

\section{Introduction}

Brazil is one of the countries with the largest agricultural production in the world. Increased production implies the generation of waste, as well as the generation of byproducts, representing about 30 to $40 \%$ of fruit processing, contributing to increased costs, losses and environmental problems. ${ }^{1}$ Residues and byproducts are mostly obtained from seeds and bark, which are the fractions with the highest lignocellulose content. ${ }^{2}$ Among the main byproducts generated in Brazil, we highlight those coming from cocoa and its co-products. Cocoa (Theobroma cacao L. (Sterculiaceae)) is a tropical fruit of great interest to the industry due to its high consumption in the national and international markets, which has led to increased production and extraction. Products of food

*e-mail: fernando.quimica@ifg.edu.br interest (i.e., liquor, chocolate) and for the cosmetic industry are generated from the fruit. ${ }^{3-6}$

The utilization of residues and byproducts from the agro-industrial process is valid, since the main component of plant biomass is lignocellulose, which represents an important source of renewable organic matter. ${ }^{7}$ Its structure consists of a complex matrix of cellulose, hemicellulose and lignin with an approximate ratio of $2: 1: 1^{8}$ and small amounts of extractives, minerals, proteins and pectin. ${ }^{9,10}$

The fungi of the genus Pycnoporus sp. are part of the large group of white decomposing basidiomycetes, capable of degrading lignocellulose. Fungi of this genus produce large amounts of enzymes capable of degrading this biopolymer such as laccase and cellulase, and are used in various biotechnology applications. ${ }^{11,12}$ For example, the fungal enzyme laccase is a multicolor oxidase that catalyzes the oxidation of phenolic molecules with the concomitant reduction of oxygen to water. 
Its versatility and substrate specificity, with its high ability to catalyze a variety of reactions, make laccase one of the most important fungal enzymes. Several applications have been reported, such as in the food industry, ${ }^{13}$ textile industry, ${ }^{14}$ nanobiotechnology. ${ }^{15}$ We highlight the application of laccase in the bioremediation of emerging pollutants, as it is an important environmental problem. ${ }^{16-18}$ Among the emerging pollutant compounds, the most worrying are the drugs and the residues of toiletries. Drugs are released into the environment through excreta ${ }^{19}$ or improper disposal ${ }^{20,21}$ and act in specific ways on organisms potentially affecting their reproduction.

Hormones such as estrone, estradiol, and ethinylestradiol are major contributors to estrogenic activity in sewage effluents and their presence in water can interfere with endogenous hormones, even at concentrations as low as $0.1 \mathrm{ng} \mathrm{L}^{-1} .{ }^{22}$ Synthetic estrogens such as $17-\alpha$-ethinylestradiol (EE2) are used as contraceptives and in hormone replacement therapies. As they are not completely metabolized by the body, they are excreted in wastewater, reaching the treatment plants. By not being degraded in treatment plants, they are released into the environment. ${ }^{23,24}$

Degradation of this type of compound poses an important ecological challenge due to its complex structures and low bioavailability. ${ }^{25}$ Conventional physical removal methods or biological treatment can only achieve partial degradation. ${ }^{26}$ Some advanced treatment processes, e.g., ozonation, advanced oxidative processes (AOPs) and reverse osmosis, effectively remove estrogens from wastewater. However, these technologies have several important disadvantages, such as high costs, time-consuming methodologies and toxic waste formation..$^{27}$ Thus, new processes are needed to remove hormones from environmental matrices in a cost-effective manner. The objective of this work was to use Pycnoporus sanguineus laccase in EE2 biodegradation, using the cocoa agro-industrial residue as the enzyme inducing agent.

\section{Experimental}

\section{Vegetal material}

The cocoa agro-industrial residue was supplied by the Natura ${ }^{\circledR}$ Plant Extraction Unit, Benevides, Pará. The plant material was dried in a forced air oven at $40{ }^{\circ} \mathrm{C}$. The processing was done by grinding and the grain size was standardized to 60 mesh. The methodology of characterization of plant material followed that described by Embrapa. ${ }^{28}$ Nitrogen content was measured by the Kjeldahl ${ }^{29}$ method. Potassium content was measured by flame photometry (Benfer BFC 150). Phosphorus, calcium, magnesium, copper, iron, manganese and zinc were analyzed by atomic absorption spectrometry (PerkinElmer model 306). Analyses were performed in triplicate. The total fiber content was made following the methodology of Scharrer and Kurschner described in the literature. ${ }^{30}$

\section{$P$. sanguineus laccase production}

The strain of Pycnoporus sanguineus American Type Culture Collection (ATCC) 4518 was obtained from the André Tosello Foundation in Campinas, São Paulo, Brazil. The fungus was kept in PDA (potato dextrose agar) medium (HiMedia, Mumbai, India) in the dark, stored at $4{ }^{\circ} \mathrm{C}$ and peaked monthly to maintain the cultures. The agroindustrial residue was added in an amount of $1 \%\left(\mathrm{~m} \mathrm{v}^{-1}\right)$ to $250 \mathrm{~mL}$ vials containing $60 \mathrm{~mL}$ of $\mathrm{PDB}(0.5 \%$ potato dextrose broth) (HiMedia, Mumbai, India) medium. The culture medium containing the residues was autoclaved at $1 \mathrm{~atm}, 120^{\circ} \mathrm{C}$ for $20 \mathrm{~min}$. Then 5 discs $(6 \mathrm{~mm})$ of the solid culture fungus were inoculated into the liquid medium containing agro-industrial residues. The flasks were incubated at $28{ }^{\circ} \mathrm{C}$ under shaking at $150 \mathrm{rpm}$ for 7 days. The assay was performed in triplicate.

Negative controls (microorganism cultured in the absence of agro-industrial residues) and positive controls (microorganism cultured in the presence of synthetic inducer) were performed. For the positive controls, the fungus was grown in malt extract (HiMedia, Mumbai, India) culture medium with $0.0005 \% \mathrm{CuSO}_{4} .5 \mathrm{H}_{2} \mathrm{O}$ (Vetec, Rio de Janeiro, Brazil) and $0.4 \mathrm{mmol} \mathrm{L}^{-1}$ of 2.5-xylidine (Sigma-Aldrich, Bellefonte, USA).

\section{Enzyme activity assay}

Laccase activity was determined every $24 \mathrm{~h}$ during 7 days of cultivation, using syringaldazine (Sigma-Aldrich, Bellefonte, USA) as substrate. A modified method based on Szklarz et al. ${ }^{31}$ was used. The components of the mixture were: $10 \mu \mathrm{L}$ of crude enzyme extract, $890 \mu \mathrm{L}$ of $50 \mathrm{mmol} \mathrm{L}^{-1}$ sodium acetate buffer $(\mathrm{pH} 5)$ and $100 \mu \mathrm{L}$ of $1.0 \mathrm{mmol} \mathrm{L}^{-1}$ syringaldazine prepared in ethanol (Merck, São Paulo, Brazil). The reaction was initiated by the addition of syringaldazine (molar extinction coefficient $\varepsilon_{525 \mathrm{~nm}}=65000 \mathrm{~L} \mathrm{~mol}^{-1} \mathrm{~cm}^{-1}$ ). One unit of enzymatic activity was defined as the amount of enzyme capable of oxidizing $1.0 \mu \mathrm{mol}$ substrate per min. The result is expressed in $\mathrm{U} \mathrm{mL}^{-1}$.

\section{Ethinylestradiol biodegradation}

A volume of $200 \mathrm{U}$ of enzymatic activity of the cocoa residue-induced crude extract was added to $150 \mathrm{~mL}$ 
Erlenmeyer flasks containing $10 \mathrm{~mL}$ of $50 \mathrm{mM}$ acetate buffer (Vetec, Rio de Janeiro, Brazil), pH 5.0, and $10 \mathrm{~mL}$ of $10 \mathrm{mg} \mathrm{L}^{-1}$ ethinylestradiol (Sigma-Aldrich, Bellefonte, USA) solution (final concentration $5 \mathrm{mg} \mathrm{L}^{-1}$ ). The vials were placed under agitation at $150 \mathrm{rpm}$ at $25^{\circ} \mathrm{C}$. After $4 \mathrm{~h}$, $200 \mu \mathrm{L}$ of $1 \mathrm{~mol} \mathrm{~L}^{-1} \mathrm{NaOH}$ solution (Vetec, Rio de Janeiro, Brazil) were added to stop the enzyme activity. Quantitative analyzes of compost degradation were performed at the State University of Campinas (UNICAMP), Chemical, Biological and Agricultural Research Center (CPQBA), following a methodology validated by Santos et al. ${ }^{32}$ The high-performance liquid chromatography (HPLC) was used under the following conditions described in Table 1.

Table 1. Chromatographic conditions

\begin{tabular}{lc}
\hline LC-DAD & Alliance Waters \\
Pump & Waters 2695 \\
Detector & Waters 2996 \\
Column & Prodigy ODS $(3)(150 \times 4.6 \mathrm{~mm})$ \\
Detection & reading $=280 \mathrm{~nm}(\mathrm{sweep}=200$ to $500 \mathrm{~nm})$ \\
Temperature $/{ }^{\circ} \mathrm{C}$ & 30 \\
Flux $/\left(\mathrm{mL} \mathrm{min}^{-1}\right)$ & 0.7 \\
Injection volume $/ \mu \mathrm{L}$ & 10 \\
Gradient elution & $\mathrm{CH}_{3} \mathrm{CN} / \mathrm{H}_{2} \mathrm{O}(1: 1)$ \\
Software & Waters Empower $^{2}$
\end{tabular}

LC-DAD: liquid chromatography-diode array detector.

In order to verify the influence of other components present in the enzymatic extract with possibility of oxidizing the hormone to be biodegraded, a control containing $10 \mathrm{~mL}$ of $50 \mathrm{mM}$ acetate buffer $\mathrm{pH} 5.0,10 \mathrm{~mL}$ of $10 \mathrm{mg} \mathrm{L}^{-1}$ ethinylestradiol solution and a volume corresponding to $200 \mathrm{U}$ of activity was carried out. However, the enzyme broth was boiled for $30 \mathrm{~min}$ for complete inactivation of the enzymes. This control was called IEC (inactive enzyme control).

It was also made a system containing only buffer and hormone solution, without addition of enzymatic extract (control hormone $(\mathrm{CH})$ ). The controls were subjected to the same conditions as the treatments for a period of $4 \mathrm{~h}$. Assays were performed in triplicate.

The percentage of removal was evaluated after 0,4 , 8 and $24 \mathrm{~h}$ of reaction, based on the control hormone concentration containing the IEC.

\section{Electrospray ionization time-of-flight mass spectrometry (ESI-TOF/MS) analysis}

In order to determine which compounds were present in the reaction medium, after enzymatic action, the samples corresponding to $\mathrm{T} 0$ and $\mathrm{T} 4$ were analyzed by direct infusion using a Microtof-QIII Mass Spectrometer Q-TOF (Bruker Daltonics, Massachusetts, USA) with electrospray ionization time-of-flight (ESI-TOF), under the following conditions: electrospray negative mode (ESI(-)); scan range $(\mathrm{m} / \mathrm{z})$ : 200-700; spray voltage: $4.0 \mathrm{kV}$; capillary temperature: $250{ }^{\circ} \mathrm{C}$; funnel: $200 \mathrm{Vpp}$.

Samples were prepared by adding $0.1 \%$ ammonium hydroxide to the solubilized sample in methanol. Controls consisted of a standard 17- $\alpha$-ethinylestradiol solution at a concentration of $5 \mathrm{mg} \mathrm{L}^{-1}$ prepared in methanol (positive control) and a solution containing all components used in biodegradation except the hormone (negative control).

\section{Results}

\section{Cocoa residue characterization}

Table 2 shows the results of the cocoa residue mineral characterization. It is noted that the copper content is $31 \mathrm{mg} \mathrm{kg}^{-1}$, which in the production medium is approximately $5 \mu \mathrm{M}$. A high total fiber content $(9.77 \%$ ) was observed, as well as trace elements such as Fe, Mn and Zn. Nitrogen content is related to the amount of protein present in plant material.

Table 2. Mean and standard deviation of trace elements and total fiber content in cocoa residue

\begin{tabular}{|c|c|}
\hline & Mean \pm standard deviation \\
\hline $\mathrm{N} /\left(\right.$ dag kg $\left.^{-1}\right)$ & $2.570 \pm 0.055$ \\
\hline $\mathrm{P} /\left(\operatorname{dag~kg}^{-1}\right)$ & $0.786 \pm 0.340$ \\
\hline $\mathrm{K} /\left(\mathrm{dag} \mathrm{kg}^{-1}\right)$ & $1.210 \pm 0.023$ \\
\hline $\mathrm{Ca} /\left(\mathrm{dag} \mathrm{kg}^{-1}\right)$ & $0.170 \pm 0.006$ \\
\hline $\mathrm{Mg} /\left(\mathrm{dag} \mathrm{kg}^{-1}\right)$ & $0.283 \pm 0.042$ \\
\hline $\mathrm{Cu} /\left(\mathrm{mg} \mathrm{kg}^{-1}\right)$ & $31.000 \pm 1.732$ \\
\hline $\mathrm{Fe} /\left(\mathrm{mg} \mathrm{kg}^{-1}\right)$ & $261.60 \pm 47.08$ \\
\hline $\mathrm{Mn} /\left(\mathrm{mg} \mathrm{kg}^{-1}\right)$ & $31.000 \pm 0.017$ \\
\hline $\mathrm{Zn} /\left(\mathrm{mg} \mathrm{kg}^{-1}\right)$ & $45.800 \pm 6.574$ \\
\hline Fiber / \% & $9.770 \pm 0.015$ \\
\hline
\end{tabular}

dag: decagram.

\section{P. sanguineus laccase production}

Figure 1 shows that there was a high laccase production during the 7 days of fungus cultivation in the presence of cocoa residue compared to the negative control of fungus grown in the absence of vegetable residue. From the third day of cultivation, enzyme production was progressive, and on the seventh day of cultivation the average laccase activity reached $3920 \mathrm{U} \mathrm{mL}^{-1}$. 


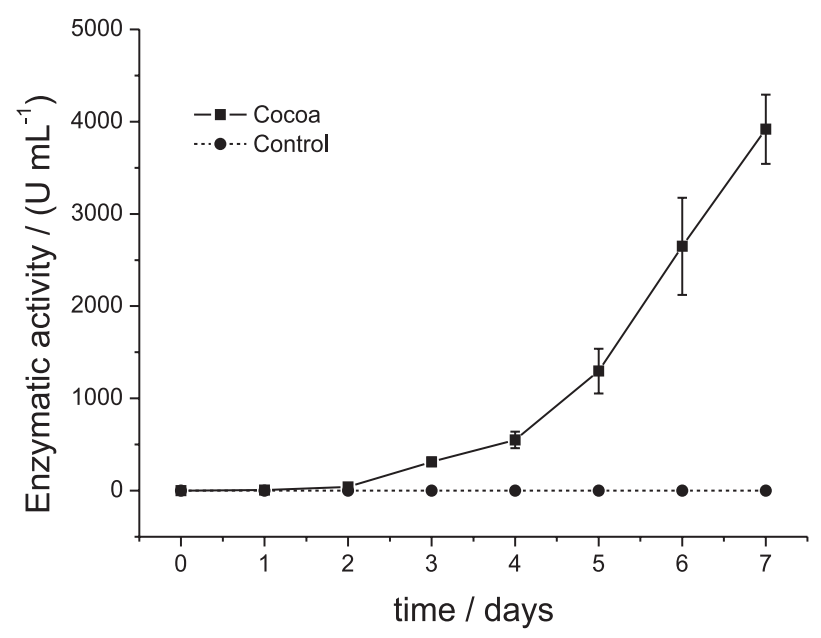

Figure 1. Enzyme activity of laccase over the 7 days of cultivation for the fungus grown in the presence of $1 \%$ cocoa residue and for the negative control without the addition of cocoa.

\section{Ethinylestradiol biodegradation}

EE2 removal capacity was evaluated using cocoa residue-induced laccase at reaction times of 4,8 and $24 \mathrm{~h}$. The reduction of the hormone concentration in the reaction medium was evaluated in relation to the initial concentration present at time 0 . As shown in Figure 2, there was a $65 \%$ reduction after $4 \mathrm{~h}$ of reaction, and after $8 \mathrm{~h}$ the concentration of EE2 present in the reaction medium was below the method limit of detection $\left(\mathrm{LOD}=0.35 \mu \mathrm{g} \mathrm{mL} \mathrm{L}^{-1}\right)$.

The mass spectrum of the samples corresponding to the initial time $\left(\mathrm{T}_{0}\right)$, which marks the beginning of the biodegradation process, showed the presence of a major peak of $\mathrm{m} / \mathrm{z} 141$ (Figure 3). Databases suggested the compound of molecular formula $\mathrm{C}_{6} \mathrm{H}_{6} \mathrm{O}_{4}$ corresponding to kojic acid. Such compound was shown to be present in all

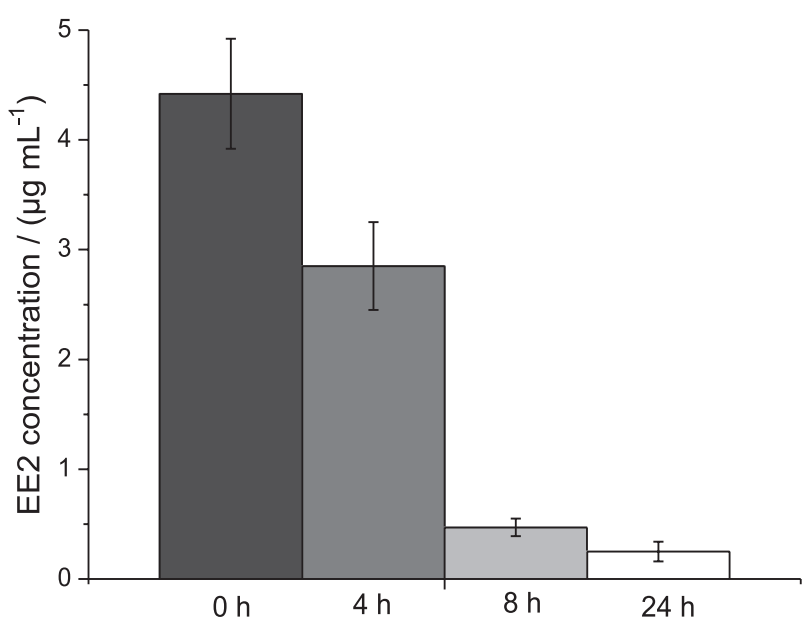

Figure 2. Concentration of EE2 in reaction media after 0, 4, 8 and $24 \mathrm{~h}$ of reaction with enzyme extract.

samples containing crude laccase extract, suggesting that it was produced by the fungus $P$. sanguineus.

A reference kojic acid sample was analyzed by mass spectrometry to confirm the identity of the $\mathrm{m} / \mathrm{z} 141$ compound. The molecule was fragmented to generate the $m / z 141,95$ and 62 ions. Fragmentation pattern of the reference kojic acid sample coincided with the fragmentation pattern of mass compound 141 present in the enzyme extract (Figure 4).

\section{Discussion}

Cocoa residue characterization and production of $P$. sanguineus laccase

The high copper content present in the cocoa residue confers enzymatic inducer characteristics. Such element, in

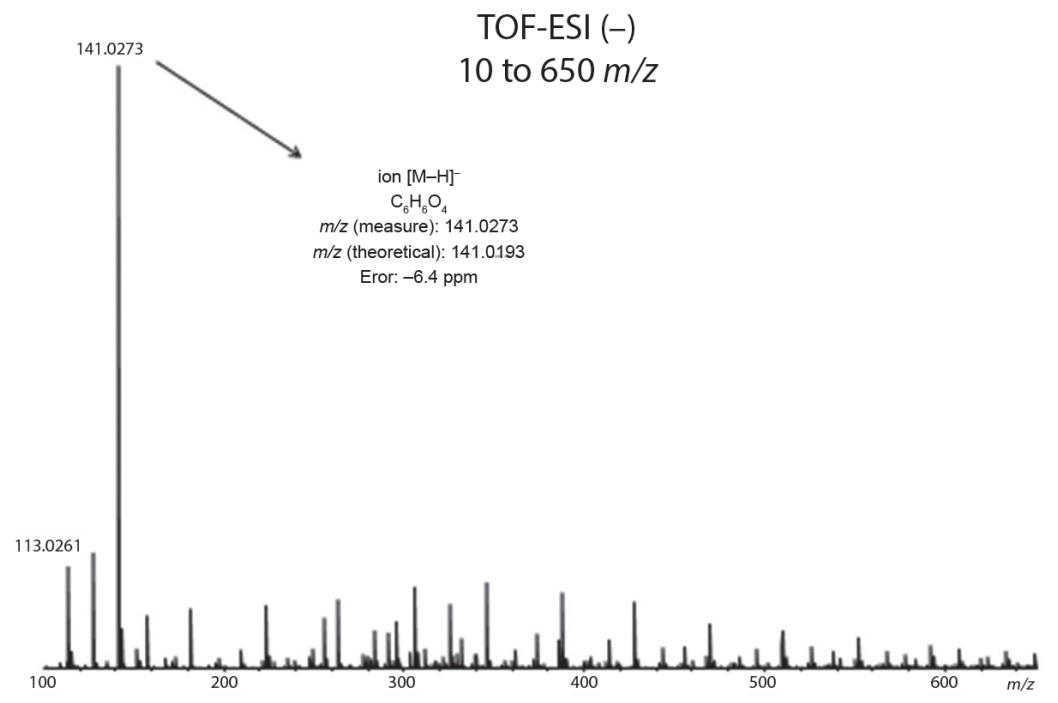

Figure 3. Mass spectrum of reaction medium at time 0, containing EE2 $\left(5 \mathrm{mg} \mathrm{L}^{-1}\right)$, crude laccase extract produced by $P$. sanguineus and acetate buffer $\mathrm{pH} 5$, showing the major peak of $\mathrm{m} / z, 141$, negative mode, TOF-ESI (-). 


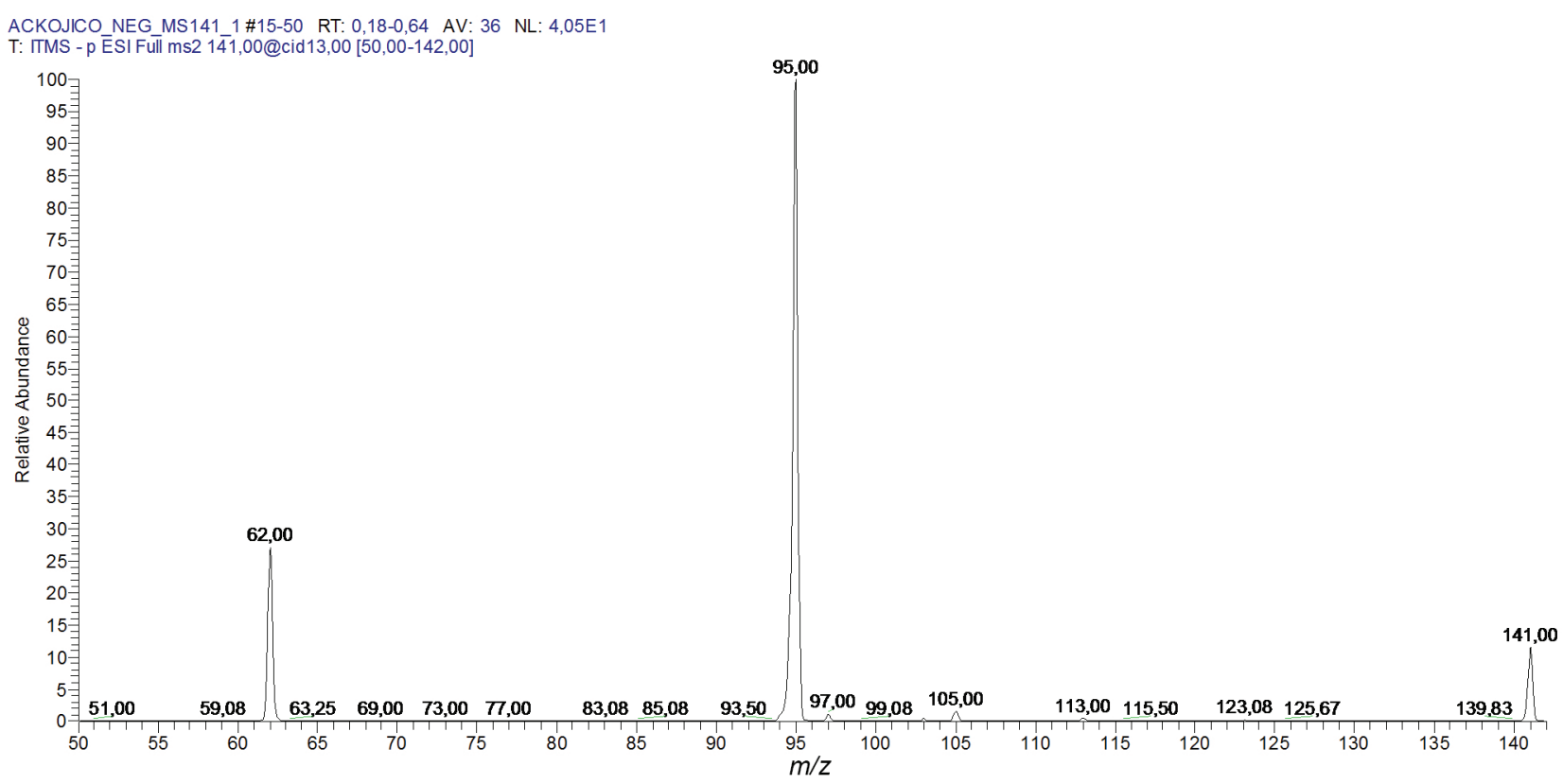

Figure 4. Mass spectrum for compound fragmentation of $m / z$ 141, with generated fragments $(\mathrm{m} / z$ 141, 95 and 62), negative mode, TOF-ESI (-).

the form of sulfate, has been added to ligninolytic fungi culture media with the objective of inducing laccase production.

In the study by Silva et al.,$^{33}$ different forms of laccase production by basidiomycete fungi were tested. The best conditions were those containing copper in the culture medium. However, when comparing the results of different studies, ${ }^{34,35}$ it is observed that the amount of copper able to act as inducer/activator is different when analyzing different fungi. For $P$. sanguineus, which was the subject of this study, studies show that the amount of copper used to increase laccase production is much lower. In the work of Ramírez-Cavazos et al., ${ }^{36}$ the addition of copper at different concentrations also had a positive effect on laccase production in different strains. For $P$. sanguineus, the best concentration was $5.0 \mathrm{mmol} \mathrm{L}^{-1}$.

It should be noted that the active site of fungal laccases is composed of copper atoms. Thus, the high content of this element in cocoa residue may contribute to high levels of laccase production. Gianfreda et al. ${ }^{37}$ related the copper ion as an inducer of laccase production.

White-decaying fungi, among them P. sanguineus, are the only organisms capable of degrading the lignin fraction of lignocellulose, making cellulose available for other microorganisms to function. ${ }^{38}$ Thus, several studies show that white-decaying fungi grow best in the presence of fiber-rich materials, i.e., lignocellulosic residues such as rice straw, ${ }^{39}$ sugarcane bagasse, ${ }^{40,41}$ waste from the olive oil industry ${ }^{42}$ and cupuaçu waste. ${ }^{17}$

In addition to the enhanced mycelial growth, increased extracellular enzyme activity in the above studies was a remarkable result. Thus, being a lignocellulosic material, agro-industrial residues have the potential to contribute to the growth of wood decomposing fungi, as well as to the higher production of their enzymes.

Authors ${ }^{41,43}$ who used agro-residues as enzyme inducers cultured the microorganisms in culture media enriched with trace elements such as $\mathrm{KH}_{2} \mathrm{PO}_{4}, \mathrm{CaCl}_{2}, \mathrm{MgSO}_{4}, \mathrm{FeSO}_{4}$ and $\mathrm{CuSO}_{4}$, as well as essential amino acids. In the present work, the culture medium contained PDB 0.5 and $1 \%$ plant material, i.e., a minimal medium, poor in nutrients, without the addition of trace elements. The levels of laccase activity achieved show the cocoa residue inducing potential, since the culture medium was not supplemented, and no synthetic inducers were added.

\section{Ethinylestradiol biodegradation}

The result achieved in the present work reveals the potential of laccase enzyme extract in the removal of EE2. Studies ${ }^{25,43,44}$ have shown that laccase estrogen bioremediation was effective not only on a laboratory scale, but also in real situations where wastewater was used, even consisting of a complex matrix containing several molecules.

In order to increase the spectrum of action of laccase, redox mediators may be added to the reaction medium. Mediators consist of low molecular weight substrates that act as an "electron carrier" between the enzyme and the target pollutant. After being oxidized by the enzyme, the mediator leaves the active site and can oxidize any substrate, which, due to its size, cannot directly enter the enzyme active site. The oxidized form of the mediator is 
structurally different from the oxidized enzyme, allowing different mechanisms of oxidation, thus increasing the range of substrates susceptible to the action of the enzyme. ${ }^{45}$

The advantage of using crude extract instead of purified enzyme is that no mediators need to be added to the reaction medium as the fungus produces natural mediators. ${ }^{46}$ As no synthetic mediators were added in this study, natural mediators produced by $P$. sanguineus present in the crude extract may have been responsible for the high percentage of hormone removal in the early hours of the biodegradation process.

With the result of mass spectrometric analysis, it was possible to confirm the presence of an $\mathrm{m} / \mathrm{z} 141$ compound in the reaction medium, which was the major compound. Fragmentation of this compound generated molecules compatible with kojic acid fragments (5-hydroxy2-hydroxymethyl-4-pyrone). It is a compound produced by fungi and bacteria. ${ }^{47,48}$ The main biosynthetic pathway of kojic acid is the conversion of starch to glucose and glucose to kojic acid. ${ }^{49}$

An important feature of kojic acid is its ability to act as a redox mediator. Thus, its proven presence in the reaction medium corroborates the fact that there are natural mediators produced by the fungus, which enhances the action of laccase on substrates, including EE2.

\section{Conclusions}

Laccase activity reached $3920 \mathrm{U} \mathrm{mL}^{-1}$ on the $7^{\text {th }}$ day of cultivation, being superior to the positive control $\left(511 \mathrm{U} \mathrm{mL}^{-1}\right)$. The percentage of EE2 removal was $63 \%$ after $4 \mathrm{~h}$, and after $8 \mathrm{~h}$ of reaction the EE2 concentration was below the limit of detection ( $\mathrm{LOD}=0.35 \mu \mathrm{g} \mathrm{mL}-1$ ). These results show that the cocoa agro-industrial residue was an efficient inducer of $P$. sanguineus laccase production when compared to the negative control without addition of this plant material to the culture medium. In cocoa residueinduced crude laccase extract, kojic acid was identified. Such compound may have acted as a mediator in the reaction of laccase with EE2, enhancing the enzymatic action in bioremediation of this compound. The EE2 bioremediation process with crude laccase extract containing kojic acid was effective, reaching minimum levels after $8 \mathrm{~h}$ of reaction. Thus, a cheap and simple alternative to remove this important pollutant was presented, with the possibility of being applied in a microcosm or on a pilot scale.

\section{Acknowledgments}

This work was supported by CAPES, Brazil; FINEP (CT-HIDRO 01/2013) and CNPq, Brazil.

\section{References}

1. Sousa, M. S. B.; Vieira, L. M.; Silva, M. J. M.; Lima, A.; Cienc. Agrotecnol. 2011, 35, 554.

2. Ajila, C. M.; Bhat, S. G.; Prasada, U. J. S. R.; Food Chem. 2007, 102, 1006.

3. Hammerstone, J. F.; Lazarus, S. A.; Mitchell, A. E.; Rucker, R.; Schmitz, H. H.; J. Agric. Food Chem. 1999, 47, 490.

4. Wollgast, J.; Anklam, E.; Food Res. Int. 2000, 33, 423.

5. Hatano, T.; Miyatake, H.; Natsume, M.; Osakabe, N.; Takizawa, T.; Ito, H.; Yoshida, T.; Phytochemistry 2002, 59, 749.

6. Silva, J. J. M.; Rogez, H.; Quim. Nova 2013, 36, 400.

7. Howard, R. L.; Abotsi, E.; Van Rensburg, E. L. J.; Howard, S.; Afr. J. Biotechnol. 2003, 2, 602.

8. Silva, R.; Haraguchi, S. K.; Muniz, E. C.; Rubira, A. F.; Quim. Nova 2009, 32, 661.

9. Dashtban, M.; Schraft, H.; Qin, W.; Int. J. Biol. Sci. 2009, 5, 578.

10. Ferraz, A. L. In Fungos Decompositores de Materiais Lignocelulósicos; Editora da Universidade de Caxias do Sul: Caxias do Sul, Brazil, 2010.

11. Meza, J. C.; Sigoillot, J. C.; Lomascolo, A.; Navarro, D.; Auria, R.; J. Agric. Food Chem. 2006, 54, 3852.

12. Teoh, Y. P.; Mashitah, M. D.; J. Appl. Sci. 2010, 10, 1036.

13. Schroeder, M.; Pöllinger-Zierler, B.; Aichernig, N.; Siegmund, B.; Guebitz, G. M.; J. Agric. Food Chem. 2008, 56, 2485.

14. Murugesan, K.; Nam, H.; Kim, Y.; Chang, Y.; Enzyme Microb. Technol. 2007, 40, 1662.

15. Arora, D. S.; Sharma, R. K.; Appl. Biochem. Biotechnol. 2009, $160,1760$.

16. Lloret, L.; Eibes, G.; Moreira, M. T.; Feijo, G.; Lema, J. M.; Environ. Sci. Technol. 2013, 47, 4536.

17. Golveia, J. C. S.; Santiago, M. F.; Sales, P. T. F.; Sartoratto, A.; Ponezi, A. N.; Thomaz, D. V.; Gil, E. S.; Bara, M. T. F.; Prep. Biochem. Biotechnol. 2018, 48, 541.

18. Folasade, M. O.; Oluwafijimi, Y. A.; Cornelius, O. F.; Int. J. Biol. Macromol. 2019, 125, 856.

19. Valcárcel, Y.; González Alonso, S.; Rodríguez-Gil, J. L.; Romo Maroto, R.; Gil, A.; Catalá, M.; Chemosphere 2011, 82, 1062.

20. Falqueto, E.; Kligerman, D. C.; Assumpção, R. F.; Cien. Saude Colet. 2010, 15, 3283.

21. Bellan, N.; Pinto, T.; Kaneko, T. M.; Moretto, L.; Braz. J. Pharm. Sci. 2012, 48, 507.

22. Lloret, L.; Eibbes, G.; Feijoo, G.; Moreira, M. T.; Lema, J. M.; J. Hazard. Mater. 2012, 213, 175.

23. Maniero, M. G.; Bila, M. D.; Dezotti, M.; Sci. Total Environ. 2008, 407, 105.

24. Cajthaml, T.; Krěsinová, Z.; Svobodová, K.; Sigler, K.; Rězanka, T.; Environ. Pollut. 2009, 157, 3325.

25. Lloret, L.; Eibbes, G.; Lú-Chau, T. A.; Moreira, M. T.; Feijoo, G.; Lema, J. M.; Biochem. Eng. J. 2010, 51, 124. 
26. Bila, D. A. F.; Montalvão, A. F.; Azevedo, D. A.; Dezotti, M.; Chemosphere 2007, 69, 736.

27. Garcia, H. A.; Hoffman, C. M.; Kinney, K. A.; Lawler, D. F.; Water Res. 2011, 45, 1921.

28. Embrapa; Manual de Análises Químicas de Solos, Plantas e Fertilizantes; Embrapa Publishing: Brasília, Brazil, 2009.

29. American Public Health Association (APHA); Standard Methods for Examination of Water and Wastewater; American Public Health Association: Washington, USA, 1999.

30. Beythien, A.; Diemair, W.; Laboratoriums-Buch Für der Lebensmittelchemiker; Verlag von Theodor Steinkopff: Dresden, Germany, 1963.

31. Szklarz, G. D.; Antibus, R. K.; Sinsabaugh, R. L.; Linkins, A. E.; J. Mycol. 1989, 81, 234.

32. Santos, I. J. S.; Grossman, M. J.; Sartoratto, A.; Ponezi, A. N.; Durrant, L. R.; Chem. Eng. Trans. 2012, 27, 169.

33. Silva, J. J.; Santana, T. T.; Oliveira, A. C. C.; Almeida, P. H.; Souza, S. G. H.; Linde, G. A.; Colauto, N. B.; Valle, J. S.; Arq. Ciênc. Vet. Zool. 2012, 15, 191.

34. Collins, P. J.; Dobson, A. D. W.; Appl. Environ. Microbiol. 1997, 63,3444

35. Sarrapat, M. C. N.; Guillén, F.; Arambarri, A. M.; Martínez, M. J.; Appl. Microbiol. Biotechnol. 2002, 68, 1534.

36. Ramírez-Cavazos, L. I.; Junghanns, C.; Ornelas-Soto, N.; Cardenas-Chavez, D. L.; Hernandez-Luna, C.; Demarche, P.; Enaud, E.; Garcia-Morales, R.; Agathos, S. N.; Parra, R.; J. Mol. Catal. B: Enzym. 2014, 108, 32.

37. Gianfreda, S.; Xu, F.; Bollag, J. M.; Biorem. J. 1999, $3,1$.

38. Parenti, A.; Muguerza, E.; Redin Iroz, A.; Omarini, A.; Conde,
E.; Alfaro, M.; Castanera, R.; Santoyo, F.; Ramírez, L.; Pisabarro, A. G.; Bioresour. Technol. 2013, 133, 142.

39. Lee, K. M.; Kalyani, D.; Tiwari, M. K.; Kim, T. S.; Dhiman, S. S.; Lee, J. K.; Kim, I. W.; Bioresour. Technol. 2012, 123, 636.

40. Fonseca-Maldonado, R.; Ribeiro, L. F.; Furtado, G. P.; Arruda, L. M.; Meleiro, L. P.; Alponti, J. S.; Botelho-Machado, C.; Vieira, D. S.; Bonneil, E.; Furriel, R. P. M.; Thibault, P.; Ward, R. J.; Process Biochem. 2014, 49, 1152.

41. Wang, F.; Hu, J. H.; Guo, C.; Liu, C. Z.; Bioresour. Technol. 2014, 166, 602.

42. Mann, J.; Markham, J. L.; Peiris, P.; Spooner-Hart, R. N.; Nair, N. G.; Int. Biodeterior. Biodegrad. 2015, 99, 138.

43. Spina, F.; Cordero, C.; Schiliró, T.; Sgorbini, B.; Pignati, C.; Gilli, G.; J. Cleaner Prod. 2015, 100, 185.

44. Auriol, M.; Filali-Meknassi, Y.; Tyagi, R. D.; Adams, C. D.; Water Res. 2007, 41, 3281.

45. Baiocco, P.; Barreca, A. M.; Fabbrini, M.; Galli, C.; Gentili, P.; Org. Biomol. Chem. 2003, 1, 191.

46. Nguyen, L. N.; Hai, F. I.; Price, W. E.; Kang, J.; Leusch, F. D. L.; Roddick, F.; Merwe, J. P. V.; Magram, S. F.; Nghiem, L. D.; Bioresour. Technol. 2016, 200, 477.

47. Correr, C. J.; Cordeiro, G.; Gasparetto, J.; Peralta-Zamora, P.; Pontarolo, R.; Acta Farm. Bonaerense 2005, 24, 416.

48. Brtko, J.; Rondahl, L.; Ficková, M.; Hudecová, D.; Eybl, V.; Uher, M.; Cent. Eur. J. Public Health 2004, 12, 16.

49. Ferreira, N. R.; Sarquis, M. I. M.; Alves, C. N.; Santos, A. S.; An. Acad. Bras. Cienc. 2010, 3, 569.

Submitted: January 21, 2020

Published online: May 29, 2020 